\title{
Heat Transfer Analysis of Gas Turbine Blade by Varying Number of Cooling Holes and at Suitable Coolant Speeds Using CFD
}

\author{
Sridevi Basavaraju ${ }^{1 *}$, Aparna Kaleru², Sharath Reddy Chintireddy ${ }^{3}$ \\ ${ }^{1}$ Department of Mechanical Engineering, Osmania University, Hyderabad 500007, India \\ ${ }^{2}$ Department of Mechanical Engineering, JNTUH College of Engineering Sultanpur, Sangareddy 500075, India \\ ${ }^{3}$ Department of Mechanical Engineering, Chaitanya Bharathi Institute of Technology (A), Hyderabad 500075, India
}

Corresponding Author Email: sridevibasavaraju@gmail.com

https://doi.org/10.18280/ijht.390320

Received: 6 September 2020

Accepted: 19 May 2021

\section{Keywords:}

turbine blade, internal cooling, cooling holes, Nusselt number, heat transfer coefficient, CFD simulation, FLUENT 14.5

\begin{abstract}
In the present work, heat transfer analysis of a gas turbine blade consisting of 5, 7, and 10 holes, coolant flowing with suitable velocities $40 \mathrm{~m} / \mathrm{s}, 75 \mathrm{~m} / \mathrm{s}$, and $110 \mathrm{~m} / \mathrm{s}$. From the results of several investigations, the suitable velocity ranges of coolant fluid have been taken. The coolant fluid used in this work is air, as it is suitable for aircraft engines working on open cycle gas turbines, and of course, it is cheaply available, and the blade material used is Inconel 718. Simulations are carried out using Computational Fluid Dynamics (CFD) software, ANSYS FLUENT 14.5. An analysis is being done on how the temperature is varying in blade with different configurations. Temperature distribution in the blade is studied and variation of different parameters like velocity, Nusselt number, heat transfer coefficient is observed. It is found that the blade cooling is maximum in the case of a blade with 10 holes and coolant inlet velocity $110 \mathrm{~m} / \mathrm{s}$. The average Nusselt number with the coolant inlet velocity of $40 \mathrm{~m} / \mathrm{s}, 75 \mathrm{~m} / \mathrm{s}$, and $110 \mathrm{~m} / \mathrm{s}$ is around 11,19 , and 21 , respectively. The lowest temperature attained by the blade on the coolant inlet surface is $1152 \mathrm{~K}$ and the coolant exit surface is $1334 \mathrm{~K}$. These two temperatures are observed when the blade has 10 cooling holes and coolant inlet velocity is $110 \mathrm{~m} / \mathrm{s}$.
\end{abstract}

\section{INTRODUCTION}

A turbine is a rotating component that uses a fluid action to produce work. In a gas turbine, compressed, high-temperature gas is the conductor. In power generation and marine applications, it is often referred to as a power turbine. For aviation purposes, it is referred to as a gas generator. One of the reasons why gas-powered engines are used to power aircraft is that they are lightweight and compact and have a high degree of power to weight ratio. The distinctness between gas turbine blades and rocket nozzles is the wall curvature. Turbine blade walls are curved in the stream-wise direction, and rocket nozzles walls can be curved in both stream-wise and span-wise directions [1]. Gas turbines are used extensively for aircraft propulsion, land-based power generation, and industrial applications. One of the critical areas of gas turbine engines is the blade tip region, concerning durability and cooling air use [2].

\section{PROBLEM STATEMENT AND METHODOLOGY}

The higher operating temperatures of hydroelectric power are used to increase the power as well efficiency of a gas turbine. The motivation behind this is that higher temperature gases yield higher energy potential. As a result of the rotation, the local heat transfers in turbine blade internal cooling passages are different from those of stationary channels [3]. However, the components and the gas system meet the high thermal load, which can cause damage [4]. HPT (High-
Pressure Turbine) blade is one of the components continuously exposed to hot gas. Turbine blades are operated at temperatures between $1200^{\circ} \mathrm{C}$ to $1500^{\circ} \mathrm{C}$ [5]. This temperature is far beyond the melting point of current materials technology. Hot gases from the combustor enter the turbine increasing heat load on the turbine components. The flow field becomes more complex when the turbine is rotating and there are differences between the high and low-pressure walls [6]. One of the components more prone to thermal failure is the blade tip region due to its intense environment and difficulty in cooling [7]. The heat transferred to the blades in the turbine depends on the turbine inlet temperature and is directly proportional [8]. Turbine blades are required to work for a longer period operating at temperatures above their melting point.

Various cooling techniques are used to reduce the ambient temperature of the blade below the melting point [9]. The way to provide acceptable cooling of the blade tips is to extract some cooling air from various coolant passages, to protect the tip surface from the hot leakage gas [10]. The performance of cooling holes placed along the pressure side tip was good for a small tip gap when compared to a large tip gap [11]. An overall benefit to the tip obtained by releasing coolant from the pressure side holes [12]. Film cooling effectiveness for the coolant injection from both tip and pressure side holes case was higher potential due to the pressure side injected coolantcarrying over the tip surface [13]. Rib arrays inside an internal cooling channel are often used in heat exchanger systems to improve the heat transfer rate [14]. Heat transfer data in internal coolant channels with film cooling extraction is important to the design of a cooling system [15]. Internal 
cooling is achieved by air circulating in several flow channels inside the body of the blade [16]. Maximizing the cooling efficiency of such passages and quantify the performance of these passages for parameters relevant to engine operating conditions have been the primary focus for several years [17]. Although detailed heat transfer measurements in coolant channels are available in the literature, to the author's knowledge, the direct combination of velocity variations, Nusselt number, and heat transfer coefficient in such ducts has not been described. The objective of this study is

- To reduce the temperature of the blade using different configurations viz., 5,7, and 10 cooling passages with cooling inlet velocities $40 \mathrm{~m} / \mathrm{s}, 75 \mathrm{~m} / \mathrm{s}$, and $110 \mathrm{~m} / \mathrm{s}$.

- To analyse the heat transfer in a blade with a different number of cooling holes with different cooling fluid flowing at different velocities i.e., a total of nine configurations are analysed.

- To analyse of heat transfer coefficient, Nusselt number, temperature, and velocity.

- To make sure that the cooling of the blade should not affect the performance of the turbine. So, our objective is not to reduce the temperature around the blade but just reduce the temperature inside the blade.

The following parameters are considered in the study to analyse the behaviour of the blade when exposed to the various boundary conditions.

- Temperature distribution in the blade is analysed and the temperature variation in the blade domain due to cooling air is also considered. The temperature variation in the cooling holes and along the length of the blade is observed.

- The velocity profile of the air in the domain is studied.

- The average Nusselt number in the cooling holes is determined when air is flowing with different velocities. The average heat transfer coefficient is found out from the Nusselt number. It is calculated using the formula: $N u=\frac{h D}{K}$.

- The heat transfer coefficient is determined. This parameter can be used to decide with the configuration that has the highest heat transfer rate.

\section{MODELLING OF GEOMETRY}

To carry out the present work, blade cooling passages and external domain are to be modelled and meshed. The model of the blade is made using Ansys 14.5 geometry, 150 coordinate points are taken to draw the blade. Coordinates of the blade are plotted and joined using the 'Spline' option. The blade sketch extruded to a length of $150 \mathrm{~mm}$ in the $\mathrm{Z}$ direction. In the $\mathrm{X}-\mathrm{Y}$ plane on the surface of the blade, a sketch for holes (Cooling Passage) is drawn. The radius of cooling will be $2 \mathrm{~mm}$, these holes will be extruded into the blade till the end i.e., to a length of $150 \mathrm{~mm}$. Extrusion is done using remove material options, the same procedure is repeated for 5, 7, and 10 holes with the same dimensions. A new sketch which is a combination of a circle and rectangle is drawn, for fluid domain. The radius of the circle is $200 \mathrm{~mm}$. The dimension of the rectangle is $500 \times 400$. These two are merged and extruded to a length of $150 \mathrm{~mm}$ in the $\mathrm{Z}$ direction. The fluid domain dimensions are selected such that the boundary layer effects are alleviated. Blade geometry is subtracted from the domain using Boolean operation. Then a new blade geometry is imported in the place of subtracted geometry to form two different domains. The same domain is used for different cases namely blade with 5, 7, and 10 cooling holes. Model of blade having 10 holes in a fluid domain is shown in Figure 1.

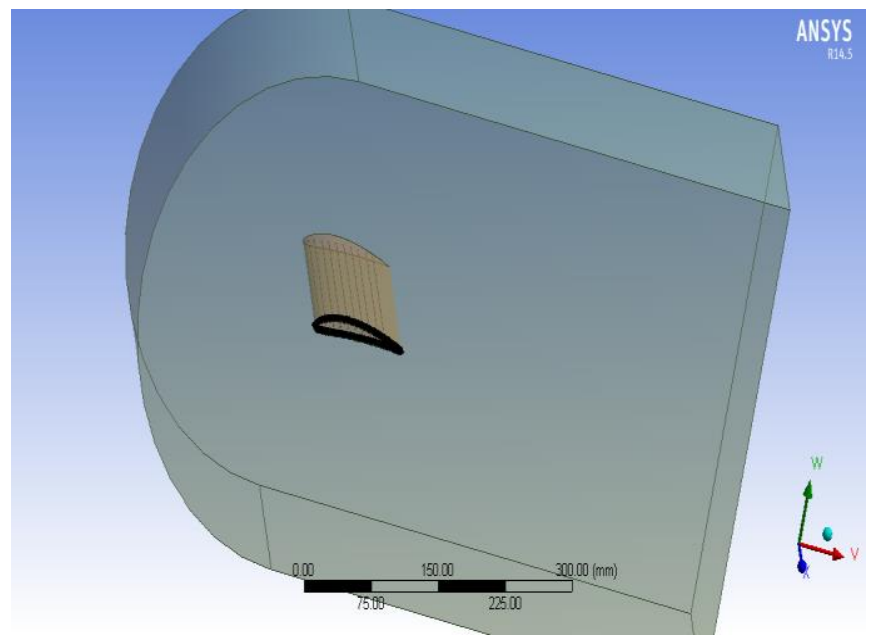

Figure 1. Model of blade having 10 holes in a fluid domain

\section{MESHING OF THE GEOMETRY}

The mesh structure of the model having domain and blade with ten coolant passages is shown in Figure 2. The minimum size of the mesh is $0.0 .001 .972 \mathrm{~m}$ and the maximum size is $0.023 .943 \mathrm{~m}$. The total number of nodes is 699,096 and the total number of elements is 604,145 . There are two types of elements in the mesh, wedges, and hexahedra. In this mesh, there are 592,439 hexahedra elements and 11,706 wedges.

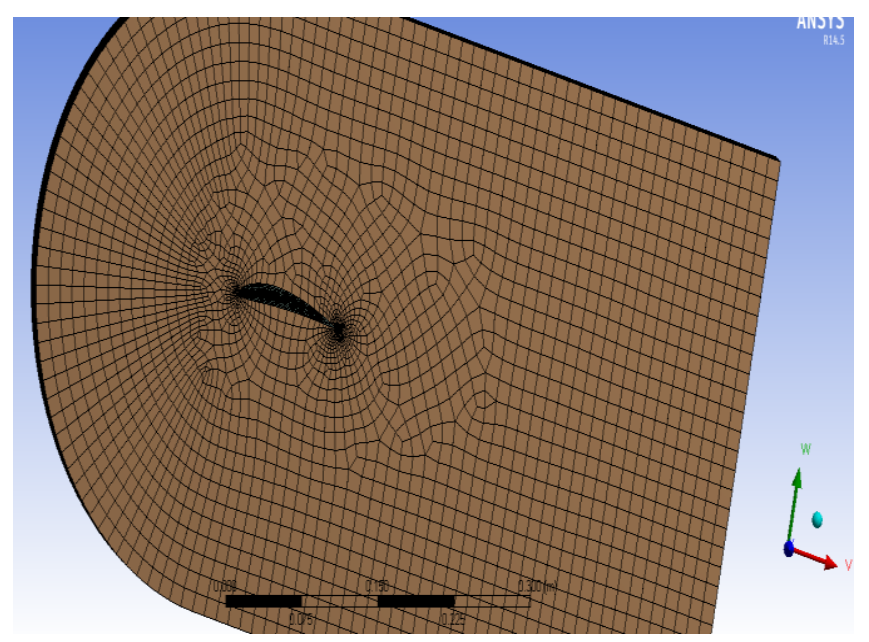

Figure 2. Mesh of blade having 10 coolant holes with domain

\section{BOUNDARY CONDITIONS}

Faces are named as inlet, outlet, coolant inlet, and a coolant outlet. Superalloy Inconel 718 is the material of the blade. The energy equation is turned $\mathrm{ON}$. As per the velocities of fluid and its properties are mentioned in Table 1, the flow will vary from transient to turbulent hence $\mathrm{k}-\varepsilon$ model is chosen to solve the problem. The properties and boundary conditions of hot and cold air are mentioned in Tables 2 and 3 respectively. 
Table 1. Properties of material Inconel 718

\begin{tabular}{c|c}
\hline Density $\left(\mathbf{k g} / \mathbf{m}^{\mathbf{3}}\right)$ & 8190 \\
Specific heat $(\mathbf{J} / \mathbf{k g ~ K})$ & 586 \\
Thermal conductivity (W/m K) & 24 \\
\hline
\end{tabular}

Table 2. Properties of hot and cold air

\begin{tabular}{ccc}
\hline Property & Hot Air & Cooling air \\
\hline Density $\left(\mathbf{k g} / \mathbf{m}^{\mathbf{3}}\right)$ & 0.615 & $\begin{array}{c}\text { Incompressible } \\
\text { Ideal Gas }\end{array}$ \\
$\begin{array}{c}\text { Specific heat }(\mathbf{J} / \mathbf{k g ~ K}) \\
\text { Thermal conductivity }\end{array}$ & 1047 & 1164 \\
$\mathbf{( W / m ~ K )}$ & 0.04605 & 0.074 \\
Viscosity $(\mathbf{k g} / \mathbf{m}-\mathbf{s})$ & $2.971 \times 10^{-5}$ & $4.5505 \times 10^{-5}$ \\
\hline
\end{tabular}

Table 3. Boundary conditions of hot air and coolant air

\begin{tabular}{ccc}
\hline & Hot Air & Cooling air \\
\hline Inlet type & Velocity inlet & Velocity inlet \\
Temperature & $1500 \mathrm{~K}$ & $400 \mathrm{~K}$ \\
Velocity & $260 \mathrm{~m} / \mathrm{s}$ & $40 \mathrm{~m} / \mathrm{s}, 75 \mathrm{~m} / \mathrm{s}, 110 \mathrm{~m} / \mathrm{s}$ \\
Pressure & $101325 \mathrm{~Pa}$ & $101325 \mathrm{~Pa}$ \\
Outlet type & Outflow & Pressure Outlet \\
\hline
\end{tabular}

\section{RESULTS AND DISCUSSIONS}

We studied heat distribution for different configurations of the blade. Gas Turbine blade with 5 holes, 7 holes, and 10 holes are studied with cooling air velocities $40 \mathrm{~m} / \mathrm{s}, 75 \mathrm{~m} / \mathrm{s}$, and $110 \mathrm{~m} / \mathrm{s}$. A total of nine cases have been studied. The temperature distribution on the blade surface is compared among all the 9 cases. The Nusselt number variation and heat transfer coefficient variation for three different velocities are represented graphically. The values of average Nusselt number obtained in the coolant passages when the coolant inlet velocities are $40 \mathrm{~m} / \mathrm{s}, 75 \mathrm{~m} / \mathrm{s}$, and $110 \mathrm{~m} / \mathrm{s}$, also the Nusselt number variation along the blade length for three different coolant inlet velocities. The calculated values of average heat transfer coefficients for the three velocities $40 \mathrm{~m} / \mathrm{s}, 75 \mathrm{~m} / \mathrm{s}$, and $110 \mathrm{~m} / \mathrm{s}$, and the variation of heat transfer coefficients for different coolant inlet velocities are presented. The values of temperatures of the blade on the coolant inlet surface for all the nine configurations i.e., 5, 7, and 10 coolant passages and $40 \mathrm{~m} / \mathrm{s}, 75 \mathrm{~m} / \mathrm{s}$, and $110 \mathrm{~m} / \mathrm{s}$ coolant inlet velocities are obtained. The temperature variation of the blade on the coolant exit surface and inlet surface at different locations for all 9 scenarios is done.

The gas turbine blade is provided with ten cooling holes. The velocity of the coolant in these holes is varied. Three velocities $40 \mathrm{~m} / \mathrm{s}, 75 \mathrm{~m} / \mathrm{s}$, and $110 \mathrm{~m} / \mathrm{s}$ are used to study the performance of the blade. The results of only 10 holes configurations are shown below in the form of contours and graphs. For remaining all other cases the tabular values are provided.

When the inlet velocity of coolant in all 10 holes is $40 \mathrm{~m} / \mathrm{s}$ the temperature contour on the blade is shown in Figure 3. From this contour, it can be said that the lowest temperature on the blade is around $1,276 \mathrm{~K}$. It is lowest near the leading edge and at the coolant inlet surface. It tends to increase along the length of the blade in $\mathrm{y}$ and $\mathrm{z}$ directions. The maximum temperature on the blade is $1,495 \mathrm{~K}$.

The area of the blade having high temperature increases from the coolant inlet surface to the exit.
Figure 4 shows the temperature distribution on the top of the blade when the coolant inlet velocity in 10 cooling holes is $75 \mathrm{~m} / \mathrm{s}$ and the hot air velocity is $260 \mathrm{~m} / \mathrm{s}$. The lowest temperature on the blade surface is around $1,279 \mathrm{~K}$. The highest temperature recorded is 1,496 K. From Figure 3 and Figure 4 it can be observed that the region having red contour i.e., the region on the blade with high temperature has reduced from Figure 3 to Figure 4.

The lowest temperature on the blade surface having 10 cooling holes and coolant flowing with $110 \mathrm{~m} / \mathrm{s}$ is around $1,237 \mathrm{~K}$. The lowest temperature is observed from the leadingedge until the position of the 7 th hole near the coolant inlet region. As the coolant flows through the hole, its temperature increases as well as blade temperature increases. This can be observed in Figure 5. The highest temperature on the blade is nearly $1,490 \mathrm{~K}$. This high temperature be a red contour on the blade near the trailing edge in Figure 5.

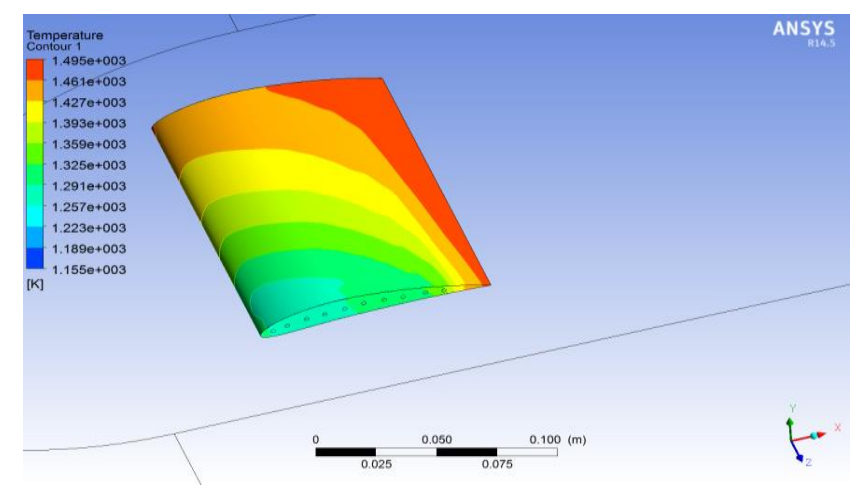

Figure 3. Temperature distribution in blade with 10 cooling holes and flow velocity $40 \mathrm{~m} / \mathrm{s}$

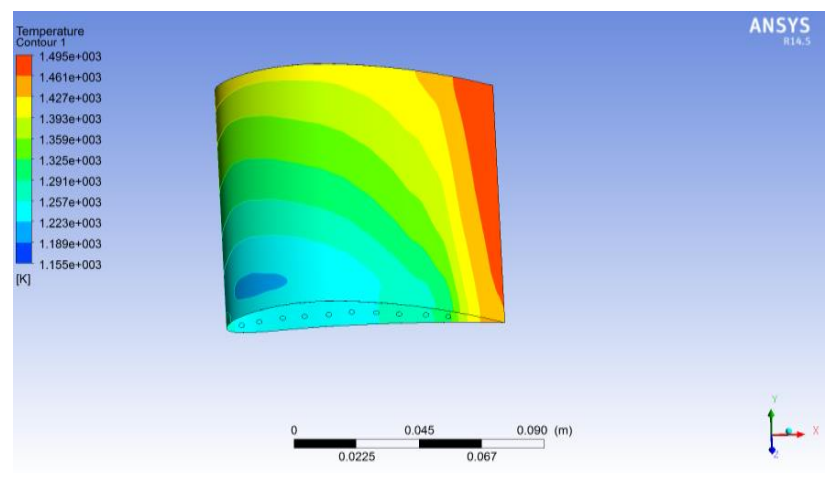

Figure 4. Temperature distribution in blade with 10 cooling holes and flow velocity $75 \mathrm{~m} / \mathrm{s}$

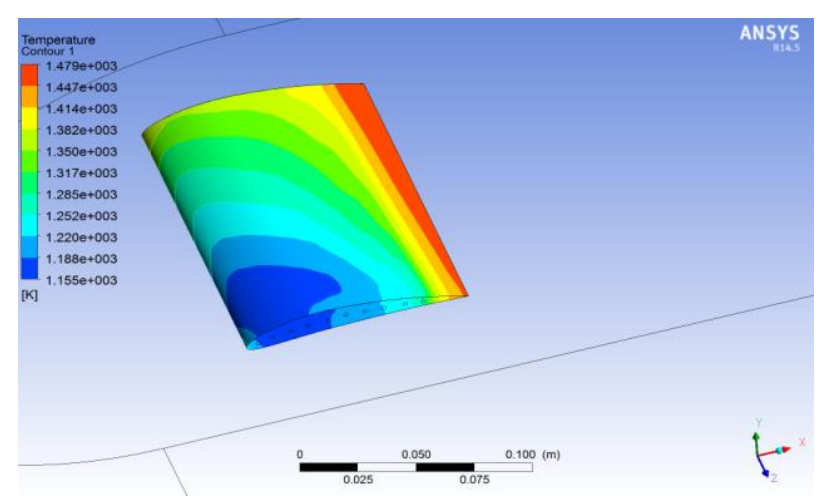

Figure 5. Temperature distribution in blade with 10 cooling holes and flow velocity $110 \mathrm{~m} / \mathrm{s}$ 
Table 4. The minimum and maximum temperature recorded on top of the blade in different cases

\begin{tabular}{cccccc}
\hline Velocity & $\begin{array}{c}\text { Temperature (K) recorded on top of } \\
\text { the blade having 5 holes } \\
\text { Minimum }\end{array}$ & Maximum & \multicolumn{2}{c}{$\begin{array}{c}\text { Temperature (K) recorded on top of } \\
\text { the blade having } 7 \text { holes } \\
\text { Minimum }\end{array}$} & \multicolumn{2}{c}{$\begin{array}{c}\text { Temperature (K) recorded on top of } \\
\text { the blade having 10 holes } \\
\text { Maximum }\end{array}$} & \multicolumn{2}{c}{ Minimum } & 1276 \\
Maximum
\end{tabular}

From Table 4, it is observed that, as the velocity of the coolant increases the temperature in the blade decreases. Every case shows same trend of increasing temperature from leading edge to trailing edge. The temperature tends to increase along the length of the blade. The minimum temperature recorded on top of the blade is $1237 \mathrm{~K}$ in case of 10 holes with $110 \mathrm{~m} / \mathrm{s}$ coolant velocity. The maximum temperature recorded on top of the blade is $1499 \mathrm{~K}$ in case of 5 holes with $75 \mathrm{~m} / \mathrm{s}$ and 110 $\mathrm{m} / \mathrm{s}$ coolant velocity.

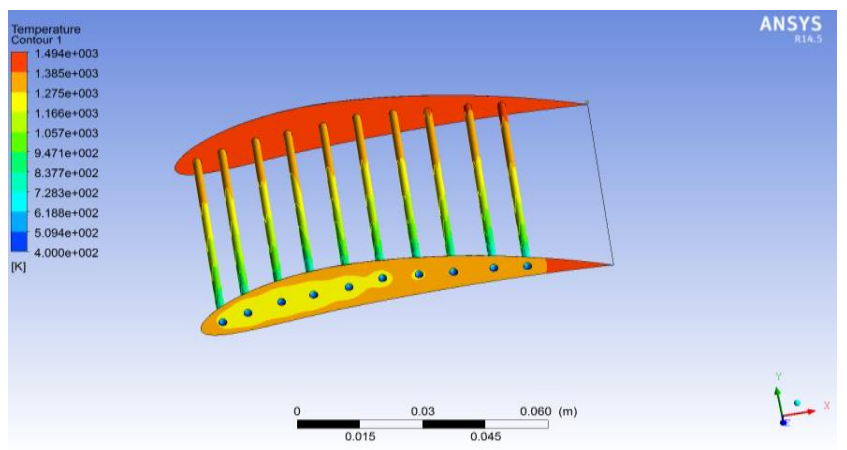

Figure 6. Temperature distribution on blade surface and coolant tubes when the coolant inlet velocity is $40 \mathrm{~m} / \mathrm{s}$

The wall temperature in the cooling holes increases from $400 \mathrm{~K}$ at the inlet to a higher temperature at the exit. Along the length of the blade, due to heat transfer, the temperature of the coolant keeps increasing. When the blade has 10 cooling holes and the inlet velocity of the coolant is $40 \mathrm{~m} / \mathrm{s}$, the temperature of the coolant wall gradually increases from $400 \mathrm{~K}$ at the inlet to nearly $1,390 \mathrm{~K}$ at the exit. This variation can be seen in Figure 6. However, the temperature of the complete flow is not the same at any location. Figure 6 gives the temperature contour of the cooling hole walls and blade surfaces at coolant inlet and exit. Figure 7 gives the temperature variation in the flow at the coolant exit hole. It can be seen that the temperature is lowest at the center of the flow and gradually increases till the walls. The lowest temperature is $1,320 \mathrm{~K}$ and the temperature at the walls is as high as $1,388 \mathrm{~K}$.

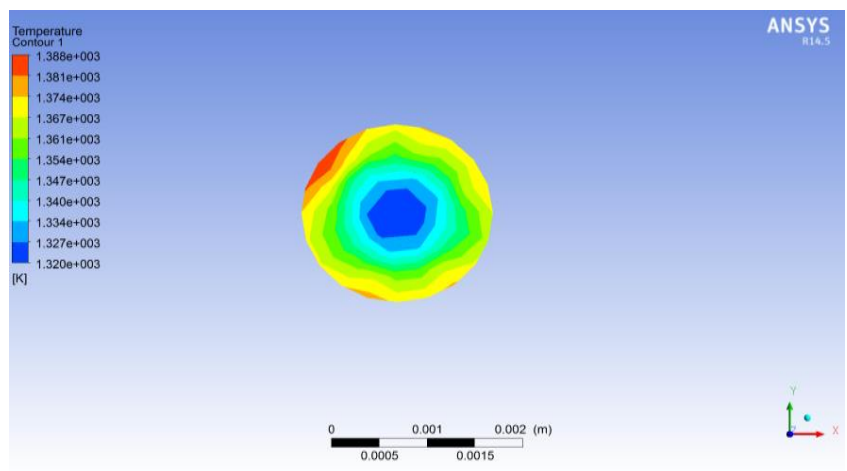

Figure 7. Temperature contour at the coolant passage exit when inlet velocity is $40 \mathrm{~m} / \mathrm{s}$

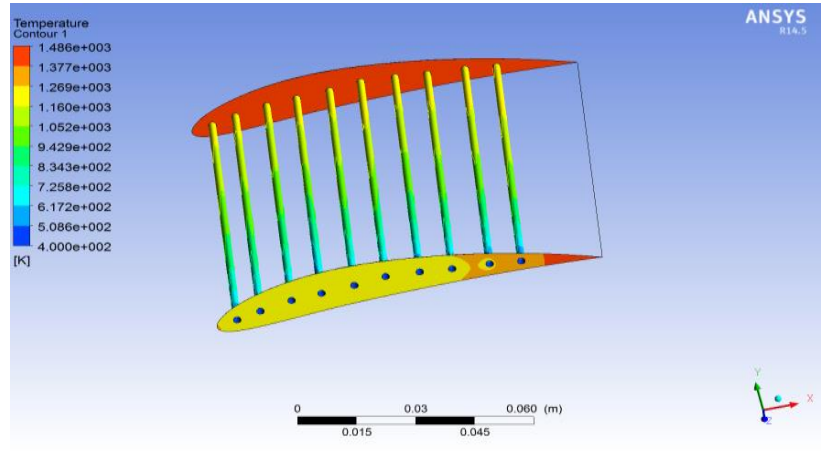

Figure 8. Temperature distribution on blade surface and coolant tubes when the coolant inlet velocity is $75 \mathrm{~m} / \mathrm{s}$

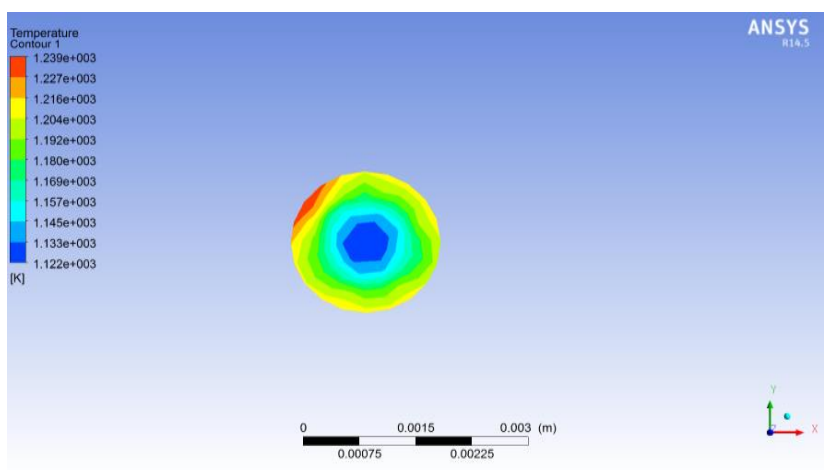

Figure 9. Temperature contour at the coolant passage exit when inlet velocity is $75 \mathrm{~m} / \mathrm{s}$

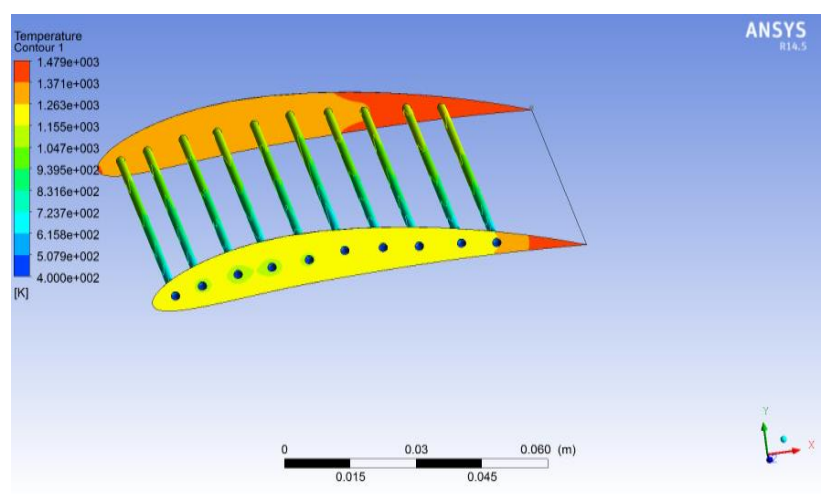

Figure 10. Temperature distribution on blade surface and coolant tubes when the coolant inlet velocity is $110 \mathrm{~m} / \mathrm{s}$

When the coolant inlet velocity is $75 \mathrm{~m} / \mathrm{s}$, the temperature of the coolant walls varies from $400 \mathrm{~K}$ at the inlet to $1,270 \mathrm{~K}$. This variation of coolant temperature can be seen in Figure 8 . At the exit of the coolant hole, the temperature distribution is shown in Figure 9. It is observed that the temperature at the center is low and increases near the walls. The temperature at the center is recorded as $1,122 \mathrm{~K}$ and the temperature near the walls is $1,238 \mathrm{~K}$. Similarly, when the coolant inlet velocity is $110 \mathrm{~m} / \mathrm{s}$, the coolant wall temperature variation is shown in 
Figure 10. The temperature at the inlet is $400 \mathrm{~K}$ at it increases to around $1,100 \mathrm{~K}$ till the coolant outlet. The temperature contour at the coolant outlet is shown in Figure 11. The temperature at the center is lower compared to the temperature near the walls. The center flow temperature is around $1,017 \mathrm{~K}$ whereas the temperature the walls at few places touches 1,155 K.

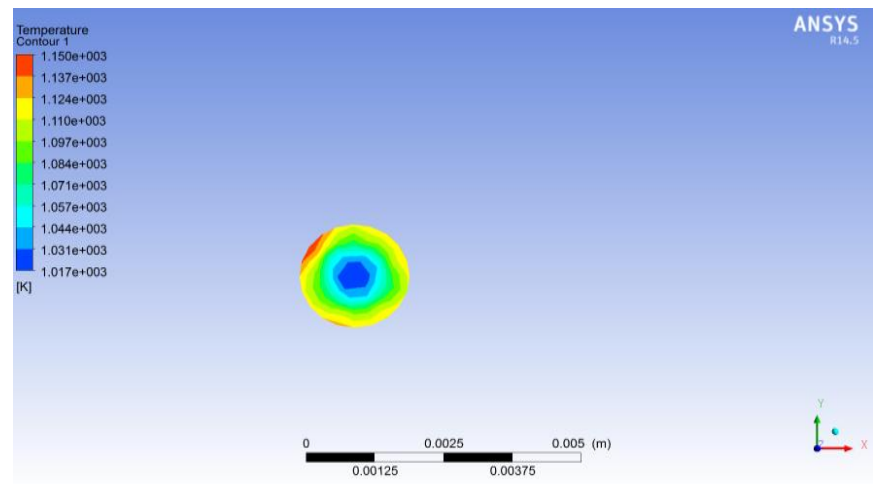

Figure 11. Temperature contour at the coolant passage exit when inlet velocity is $110 \mathrm{~m} / \mathrm{s}$

The temperature variation on the blade surface where there is coolant velocity is observed. These results for coolant inlet velocity $40 \mathrm{~m} / \mathrm{s}, 75 \mathrm{~m} / \mathrm{sand} 110 \mathrm{~m} / \mathrm{s}$ are tabulated in Tables 5 , and 6 , respectively. The temperature of the blade on the coolant inlet surface at different $\mathrm{x}$ coordinates and blade temperature on at the same $\mathrm{x}$ coordinates but on the coolant exit surface are noted.
From Table 5 it can be observed that the temperature at the leading edge on the coolant inlet surface i.e., at $\mathrm{x}=0 \mathrm{~m}$, the temperature is $1,347 \mathrm{~K}$ and it tends to decrease till $\mathrm{x}=0.02 \mathrm{~m}$. It means till half the chord length the temperature reduces and from there again it starts increasing till the trailing edge. At the coolant exit surface the temperature on the blade is $1,490 \mathrm{~K}$ at the leading edge and it till the position $\mathrm{x}=0.02 \mathrm{~m}$. From there it tends to increase till the trailing edge. The highest temperature observed will be $1,496.4 \mathrm{~K}$ at $\mathrm{x}=0.1 \mathrm{~m}$ and $\mathrm{y}=$ $0.15 \mathrm{~m}$.

When the coolant inlet velocity is $75 \mathrm{~m} / \mathrm{s}$ the temperature distribution on the blade surfaces is given in Table 5. It is observed that the lowest temperature is noted at $\mathrm{x}=0.02 \mathrm{~m}$. the lowest temperature recorded is around $1,257 \mathrm{~K}$, which is nearly equal to that previous case. The blade temperature on the coolant exit surface is given in the third column of the table. The temperature decreases from the leading edge to the position of $\mathrm{x}=0.02 \mathrm{~m}$. The lowest temperature on that surface is $1,452.7 \mathrm{~K}$, which also equal to the previous case.

The temperature distribution where the coolant velocity is $110 \mathrm{~m} / \mathrm{s}$ is tabulated in Table 6 . The lowest blade temperature recorded on the coolant inlet surface is around $1,217 \mathrm{~K}$ and the highest is $1,471 \mathrm{~K}$. A sharp rise in the blade in temperature can be observed from $\mathrm{x}=0.08$ to $\mathrm{x}=0.1 \mathrm{~m}$. On the coolant exit surface, the temperature varies from $1,414 \mathrm{~K}$ to $1,492 \mathrm{~K}$, the lowest temperature occurring at $\mathrm{x}=0.02 \mathrm{~m}$. Even on this surface, there is a sharp rise in temperature near the trailing edge. The temperature distribution of blade on coolant inlet and outlet surface along chord length for different cases is shown in Figures 12 and 13 respectively.

Table 5. Temperature distribution of blade on coolant inlet surface along chord length for different cases

\begin{tabular}{|c|c|c|c|c|c|c|c|c|c|}
\hline \multirow[t]{2}{*}{$\mathbf{x}(\mathbf{m})$} & \multicolumn{3}{|c|}{$\begin{array}{l}\text { Blade temperature (K) having } 5 \\
\text { holes with coolant velocity }\end{array}$} & \multicolumn{3}{|c|}{$\begin{array}{c}\text { Blade temperature (K) having } 7 \text { holes } \\
\text { with coolant velocity }\end{array}$} & \multicolumn{3}{|c|}{$\begin{array}{l}\text { Blade temperature (K) having } 10 \text { holes } \\
\text { with coolant velocity }\end{array}$} \\
\hline & $40 \mathrm{~m} / \mathrm{s}$ & $75 \mathrm{~m} / \mathrm{s}$ & $110 \mathrm{~m} / \mathrm{s}$ & $40 \mathrm{~m} / \mathrm{s}$ & $75 \mathrm{~m} / \mathrm{s}$ & $110 \mathrm{~m} / \mathrm{s}$ & $40 \mathrm{~m} / \mathrm{s}$ & $75 \mathrm{~m} / \mathrm{s}$ & $110 \mathrm{~m} / \mathrm{s}$ \\
\hline 0 & 1386.8 & 1348.0 & 1315.5 & 1360 & 1335.4 & 1293.6 & 1309.8 & 1270.6 & 1226.6 \\
\hline 0.02 & 1354.3 & 1274.4 & 1255.1 & 1310.6 & 1300.1 & 1252.6 & 1262.1 & 1205.2 & 1152.5 \\
\hline 0.04 & 1366.5 & 1320.8 & 1280.5 & 1307.1 & 1288.6 & 1233.2 & 1271.6 & 1221.8 & 1163.3 \\
\hline 0.06 & 1374.1 & 1333.9 & 1301.6 & 1337.6 & 1309.6 & 1261.6 & 1286.1 & 1243.9 & 1193.7 \\
\hline 0.08 & 1466.5 & 1459.7 & 1450.9 & 1412.6 & 1396.4 & 1376.06 & 1332.2 & 1300.8 & 1267.5 \\
\hline 0.1 & 1492.8 & 1489.2 & 1490.9 & 1483.9 & 1486.6 & 1479.6 & 1482.1 & 1468.6 & 1466.5 \\
\hline
\end{tabular}

\section{Temperature Vs Chord length}

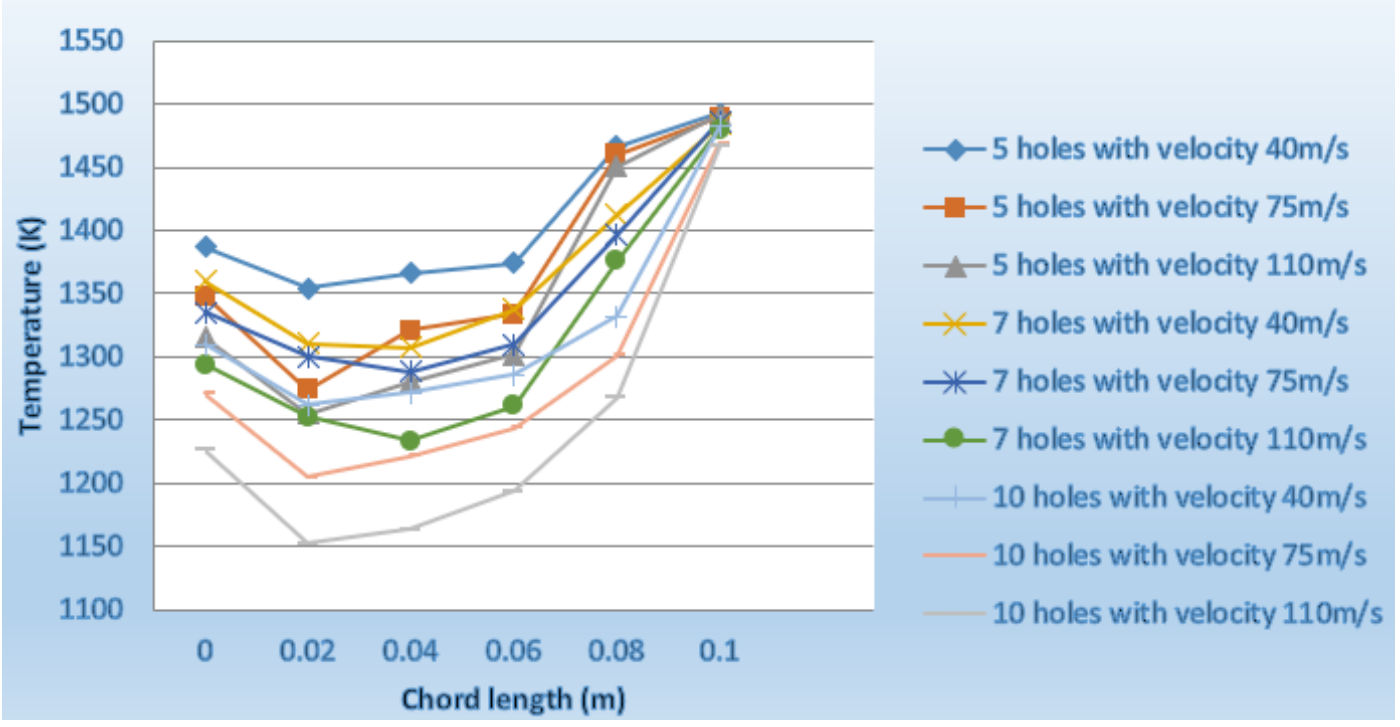

Figure 12. Temperature distribution of blade on coolant inlet surface along chord length for different cases 
Table 6. Temperature distribution of blade on coolant outlet surface along chord length for different cases

\begin{tabular}{|c|c|c|c|c|c|c|c|c|c|}
\hline \multirow[t]{2}{*}{$\mathbf{x}(\mathbf{m})$} & \multicolumn{3}{|c|}{$\begin{array}{l}\text { Blade temperature }(\mathrm{K}) \text { having } 5 \\
\text { holes with coolant velocity }\end{array}$} & \multicolumn{3}{|c|}{$\begin{array}{l}\text { Blade temperature }(\mathrm{K}) \text { having } 7 \text { holes } \\
\text { with coolant velocity }\end{array}$} & \multicolumn{3}{|c|}{$\begin{array}{l}\text { Blade temperature }(\mathrm{K}) \text { having } 10 \text { holes } \\
\text { with coolant velocity }\end{array}$} \\
\hline & $40 \mathrm{~m} / \mathrm{s}$ & $75 \mathrm{~m} / \mathrm{s}$ & $110 \mathrm{~m} / \mathrm{s}$ & $40 \mathrm{~m} / \mathrm{s}$ & $75 \mathrm{~m} / \mathrm{s}$ & $110 \mathrm{~m} / \mathrm{s}$ & $40 \mathrm{~m} / \mathrm{s}$ & $75 \mathrm{~m} / \mathrm{s}$ & $110 \mathrm{~m} / \mathrm{s}$ \\
\hline 0 & 1483.7 & 1446.8 & 1420.1 & 1499.8 & 1499.7 & 1498.6 & 1499.3 & 1412.4 & 1372.6 \\
\hline 0.02 & 1477.6 & 1425.6 & 1390.9 & 1453.6 & 1439.6 & 1390.2 & 1450.7 & 1389.5 & 1334.7 \\
\hline 0.04 & 1479.4 & 1437.6 & 1405.8 & 1452 & 1432.4 & 1388.7 & 1455.4 & 1395.5 & 1347.5 \\
\hline 0.06 & 1482.9 & 1448.8 & 1421.5 & 1468.1 & 1437.7 & 1403.2 & 1462.6 & 1409.2 & 1366.8 \\
\hline 0.08 & 1494.5 & 1486.2 & 1479.1 & 1484.8 & 1466.6 & 1451.4 & 1475 & 1439 & 1409.3 \\
\hline 0.1 & 1498.8 & 1496 & 1494.3 & 1496.6 & 1494.4 & 1493.8 & 1496.4 & 1490.5 & 1488.5 \\
\hline
\end{tabular}

\section{Temperature Vs Chord length}

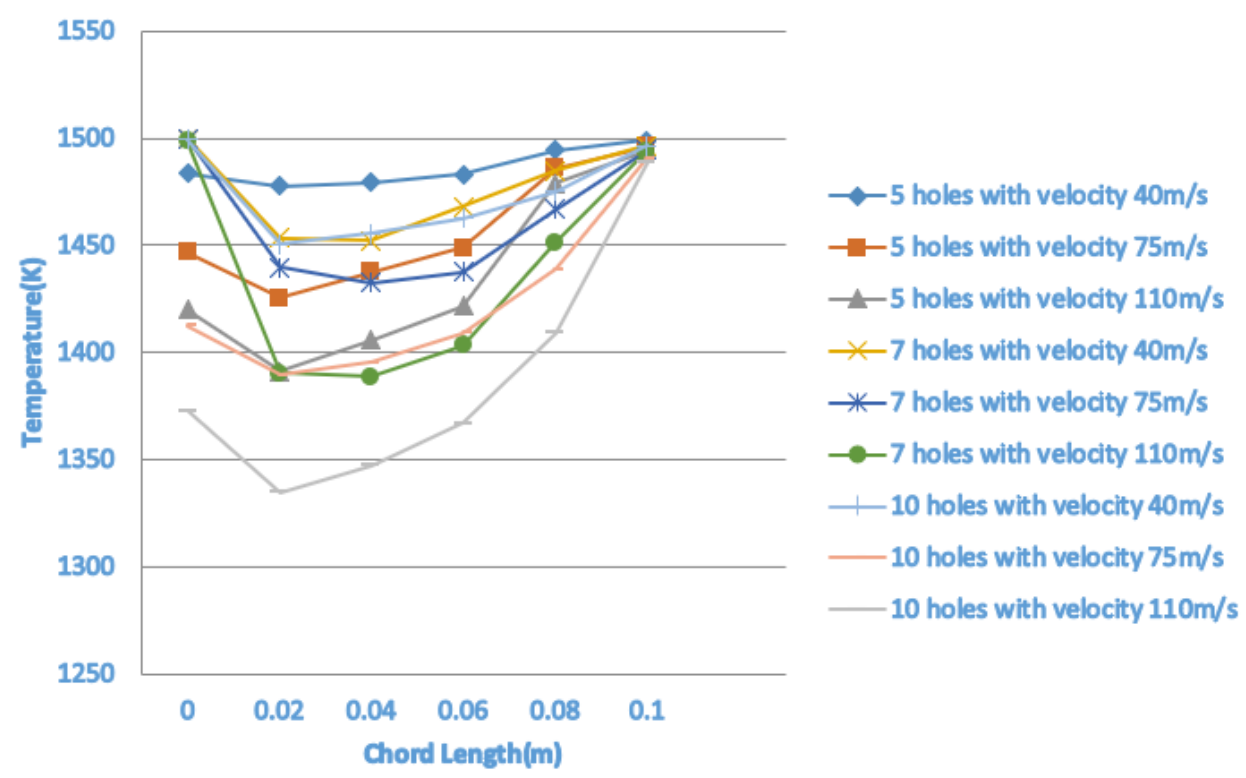

Figure 13. Temperature distribution of blade on coolant outlet surface along chord length for different cases

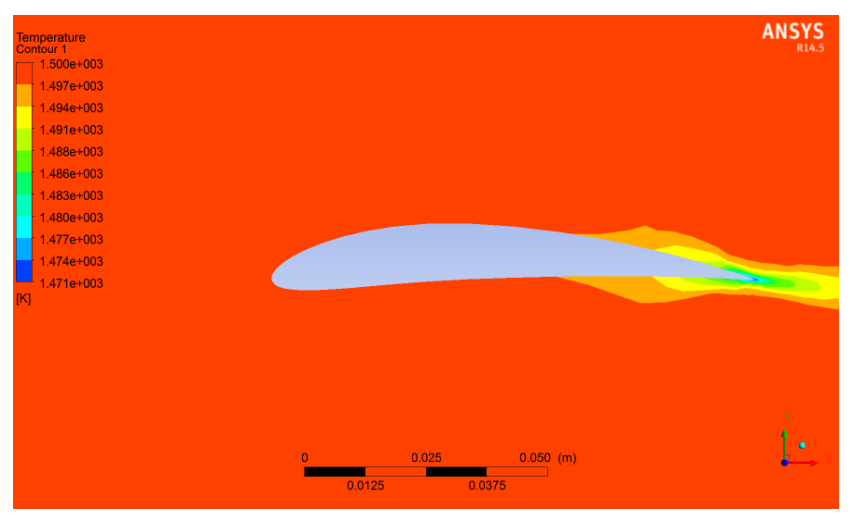

Figure 14. Temperature distribution in the domain with blade having 7 holes and flow velocity $40 \mathrm{~m} / \mathrm{s}$

When the coolant of lower temperature is passed through the blade and the coolant mixes with the main flow and hence it reduces the temperature of the surroundings a little. As the velocity of coolant increases the temperature reduction around the blade also increases. When the coolant inlet velocity is 40 $\mathrm{m} / \mathrm{s}$ and there are 10 coolant holes present on the blade, the domain temperature contour is shown in Figure 14. It is observed that the temperature near the blade has reduced. The minimum temperature of $1,471 \mathrm{~K}$ is found at the trailing edge of the blade, which means there is a reduction of $29^{\circ}$ from the mainstream temperature. When the Coolant inlet velocity is 75 $\mathrm{m} / \mathrm{s}$, it is observed that there is a maximum reduction of $36^{\circ}$ near the trailing edge of the blade. It can be seen in Figure 15 that temperature is lowest at the trailing edge and gradually increases to normal flow temperature. The temperature reduces by $43^{\circ}$ when the coolant inlet velocity is $110 \mathrm{~m} / \mathrm{s}$. The temperature of the fluid around the blade is recorded as 1,467 $\mathrm{K}$. The temperature contour of the domain when the coolant inlet velocity is $110 \mathrm{~m} / \mathrm{s}$ is shown in Figure 16 .

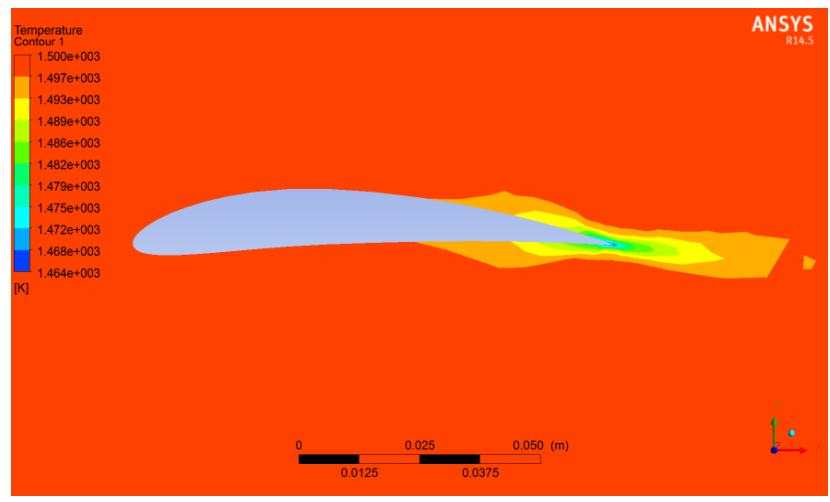

Figure 15. Temperature distribution in domain with blade having 10 cooling holes and flow velocity $75 \mathrm{~m} / \mathrm{s}$

The velocity contour of the domain is shown in Figure 17. It was observed that the contour was almost similar even when the coolant inlet was varied. The velocity of the hot air in the domain increases on reaching the blade. The velocity is highest on top of the blade which is nearly is $600 \mathrm{~m} / \mathrm{s}$. It reduces as the flow moves away from the blade. Due to 
boundary conditions, the velocity near the walls approaches to zero.

The velocity profile of the coolant at the exit is shown in Figures 18, Figure 19, and Figure 20 when the inlet velocity is $40 \mathrm{~m} / \mathrm{s}, 75 \mathrm{~m} / \mathrm{s}$, and $110 \mathrm{~m} / \mathrm{s}$, respectively. The velocity is highest in the center of the flow and reduces near the walls. When the coolant inlet velocity is $40 \mathrm{~m} / \mathrm{s}$ the velocity at the center of the exit is $164 \mathrm{~m} / \mathrm{s}$ and near the walls, it is $103 \mathrm{~m} / \mathrm{s}$. The velocity of coolant at the center at the exit is $258 \mathrm{~m} / \mathrm{s}$ and $178 \mathrm{~m} / \mathrm{s}$ at the walls when the inlet velocity $75 \mathrm{~m} / \mathrm{s}$. Similarly, when the coolant inlet velocity is $110 \mathrm{~m} / \mathrm{s}$, the velocity of the center of flow is $346 \mathrm{~m} / \mathrm{s}$ and at the walls is $243 \mathrm{~m} / \mathrm{s}$. The variation of Nusselt Number and Heat Transfer Coefficient along length ( $\mathrm{z}$ ) of blade for different velocities is shown in Figures 21 and 22 respectively.

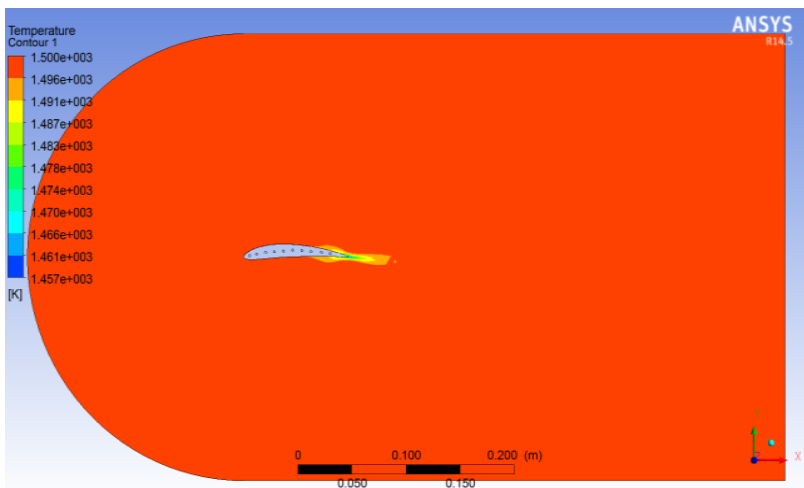

Figure 16. Temperature distribution in the domain with blade having 10 cooling holes and flow velocity $110 \mathrm{~m} / \mathrm{s}$

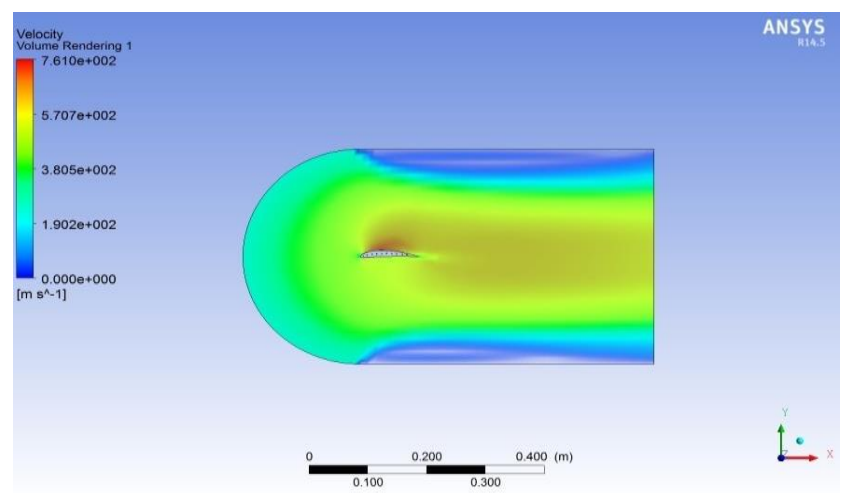

Figure 17. Velocity distribution in the domain with blade having 10 holes and flow velocity $40 \mathrm{~m} / \mathrm{s}$

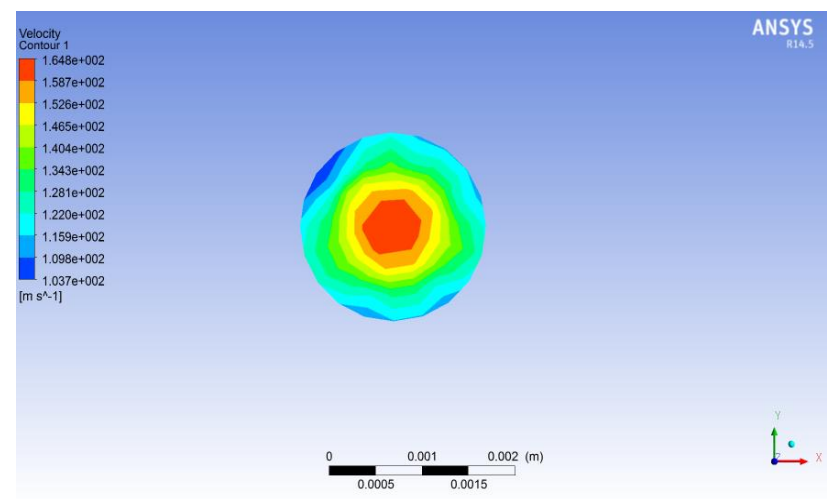

Figure 18. Velocity contour at the coolant outlet when the inlet velocity is $40 \mathrm{~m} / \mathrm{s}$

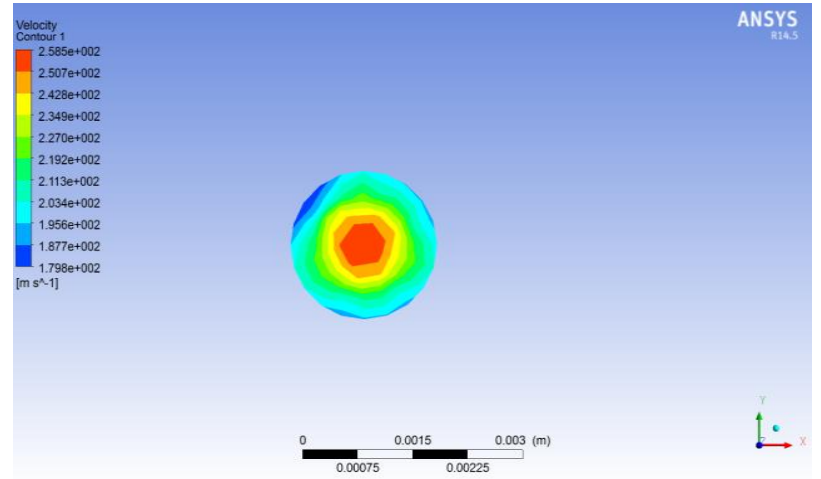

Figure 19. Velocity contour at the coolant outlet when the inlet velocity is $75 \mathrm{~m} / \mathrm{s}$

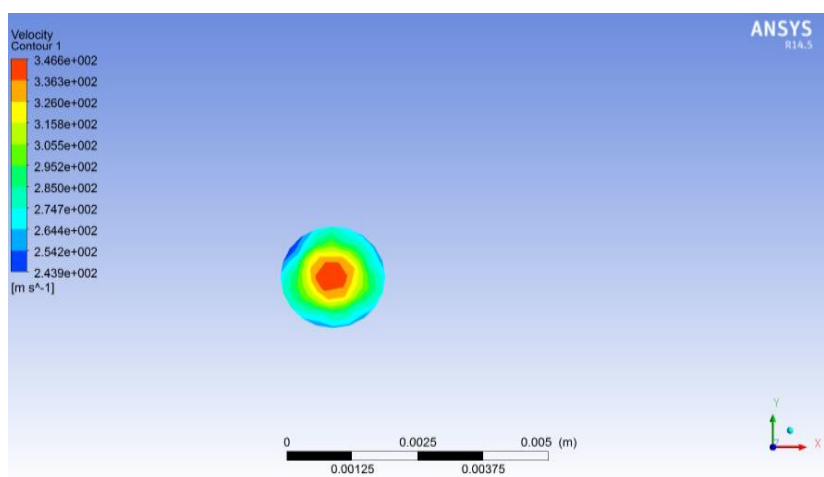

Figure 20. Velocity contour at the coolant outlet when the inlet velocity is $110 \mathrm{~m} / \mathrm{s}$

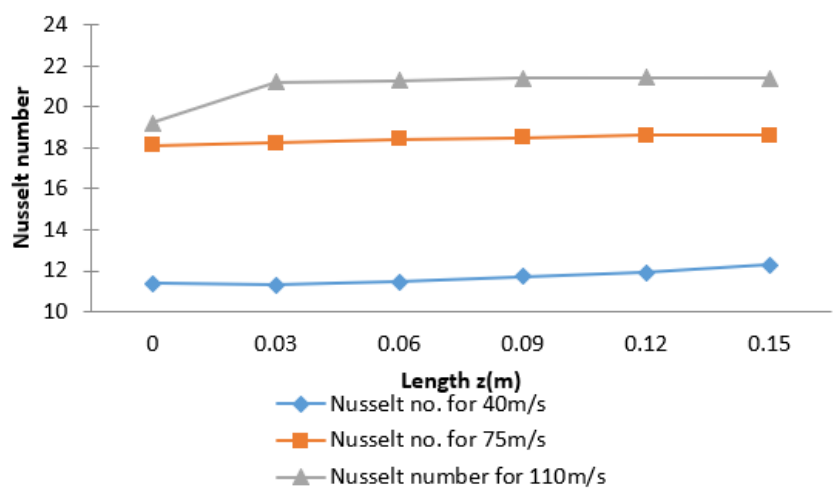

Figure 21. Nusselt number variation along length(z) of blade for different velocities

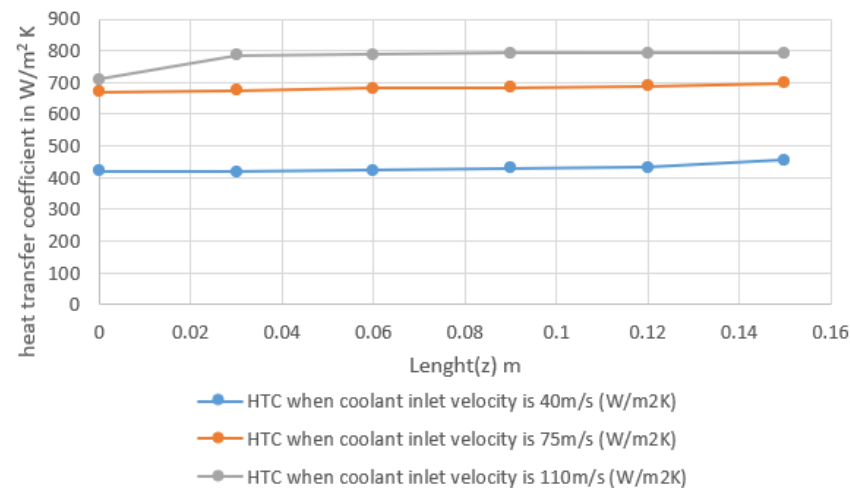

Figure 22. Heat transfer coefficient variation along length(z) of blade for different for velocities 
Table 7. Nusselt number distribution along blade length

\begin{tabular}{cccc}
\hline \multirow{2}{*}{$\mathbf{z}(\mathbf{m})$} & \multicolumn{3}{c}{ Nusselt number when coolant inlet velocity is } \\
& $\mathbf{4 0} \mathbf{~ m} / \mathbf{s}$ & $\mathbf{7 5} \mathbf{~ m} / \mathbf{s}$ & $\mathbf{1 1 0 ~ \mathbf { ~ } / \mathbf { s }}$ \\
\hline 0 & 11.36 & 18.13 & 19.2 \\
0.03 & 11.3 & 18.22 & 21.2 \\
0.06 & 11.45 & 18.42 & 21.3 \\
0.09 & 11.7 & 18.5 & 21.4 \\
0.12 & 11.9 & 18.6 & 21.45 \\
0.15 & 12.3 & 19 & 21.41 \\
\hline
\end{tabular}

Table 8. Heat transfer coefficient distribution along blade length

\begin{tabular}{|c|c|c|c|}
\hline \multirow{3}{*}{$\mathbf{z}(\mathbf{m})$} & \multicolumn{3}{|c|}{ Heat Transfer Coefficient when coolant inlet velocity } \\
\hline & & is & \\
\hline & $40 \mathrm{~m} / \mathrm{s}$ & $75 \mathrm{~m} / \mathrm{s}$ & $110 \mathrm{~m} / \mathrm{s}$ \\
\hline 0 & 420.46 & 670.9 & 710.6 \\
\hline 0.03 & 418.2 & 674.32 & 784.6 \\
\hline 0.06 & 423.7 & 681.72 & 788.3 \\
\hline 0.09 & 430.67 & 684.7 & 792 \\
\hline 0.12 & 431.9 & 688.4 & 792.4 \\
\hline 0.15 & 455.2 & 698.4 & 792.1 \\
\hline
\end{tabular}

The Nusselt Number and Heat Transfer Coefficient distribution along blade length are shown in Table 7 and 8 respectively. Like the way it has been solved for 10 cooling holes, the same procedure is followed for 5 and 7 cooling holes. The temperature and velocity distribution, Nusselt number, and heat transfer coefficient are obtained and the combined representation of various cooling holes is done above.

\section{CONCLUSIONS}

In the present work heat transfer analysis on a gas turbine with different number of cooling passages is studied. Gas turbine blade with five, seven, and ten cooling holes are taken, and coolant inlet velocities $40 \mathrm{~m} / \mathrm{s}, 75 \mathrm{~m} / \mathrm{s}$, and $110 \mathrm{~m} / \mathrm{s}$ are given. Hence a total of nine different configurations are studied. The conclusions of the current work are given as follows:

- The highest average Nusselt number 21 is observed in the case where the coolant is flowing with $110 \mathrm{~m} / \mathrm{s}$.

- Among the considered configurations i.e., $40 \mathrm{~m} / \mathrm{s}, 75$ $\mathrm{m} / \mathrm{s}$ and $110 \mathrm{~m} / \mathrm{s}$, maximum heat transfer coefficient is found to be around $780 \mathrm{~W} / \mathrm{m}^{2} \mathrm{~K}$. It is observed when the coolant inlet velocity is $110 \mathrm{~m} / \mathrm{s}$.

- The variation of Nusselt number and heat transfer coefficient are high between the cases with coolant velocity $40 \mathrm{~m} / \mathrm{s}$ and $75 \mathrm{~m} / \mathrm{s}$.

- When the temperature distribution on the blade surface along chord length is observed, maximum temperature is reduced when there 10 cooling holes with coolant flowing at $110 \mathrm{~m} / \mathrm{s}$.

- The minimum temperature of blade at the coolant exit surface of the coolant is observed in the case with 10 cooling holes with coolant flowing at $110 \mathrm{~m} / \mathrm{s}$ followed by 7 holes with $110 \mathrm{~m} / \mathrm{s}$.

- The temperature of coolant has been increasing along the passage from $400 \mathrm{~K}$ to $1400 \mathrm{~K}$ as it absorbs heat from the blade and the maximum temperature difference is observed in the case of blade with 5 cooling holes with the velocity of $40 \mathrm{~m} / \mathrm{s}$ followed by 7 cooling holes with $40 \mathrm{~m} / \mathrm{s}$ and 10 cooling holes with
$40 \mathrm{~m} / \mathrm{s}$ and then 7 cooling holes with $75 \mathrm{~m} / \mathrm{s}$.

- In the case of blade having 10 holes and coolant flowing with $110 \mathrm{~m} / \mathrm{s}$, the temperature in the domain around the blade is reducing by around $43 \mathrm{~K}$ which is not desirable. So, the blade with 5 holes and coolant flowing with $40 \mathrm{~m} / \mathrm{s}$ seems to be desirable as the temperature in the domain around the blade is reducing by around $10 \mathrm{~K}$.

- It is desirable to consider a blade with 5 cooling holes with $40 \mathrm{~m} / \mathrm{s}$ as the variation of Nusselt number and heat transfer coefficient are high between the cases with coolant velocity $40 \mathrm{~m} / \mathrm{s}$ and $75 \mathrm{~m} / \mathrm{s}$ and also the temperature distribution around the domain is desirable in this case.

\section{REFERENCES}

[1] Guelailia, A., Khorsi, A., Boudjemai, A., Wang, J. (2018). Thermal protection of rocket nozzle by using film cooling technology - effect of lateral curvature. International Journal of Heat and Technology, 36(3): 1070-1074. https://doi.org/ 10.18280/ijht.360338

[2] Downs, J.P., Abdel-Messeh, W., Steuber, G.D., Tanrikut, S. (1995). A summary of the cooled turbine blade tip heat transfer and film effectiveness investigations performed by Dr. DE Metzger. Journal of Turbomachinery, 117(1): 1-11. https://doi.org/10.1115/94-GT-167

[3] Chen, H.C., Jang, Y.J., Han, J.C. (2000). Near-wall second-moment closure for rotating multiple-pass cooling channels. Journal of Thermophysics and Heat Transfer, 14(2): 201-209. https://doi.org/10.2514/2.6509

[4] Han, J.C. (2004). Recent studies in turbine blade cooling. International Journal of Rotating Machinery, 10(6): 443457. https://doi.org/10.1155/S1023621X04000442

[5] Han, J.C., Chen, H.C. (2006). Turbine blade internal cooling passages with rib turbulators. Journal of Propulsion and Power, 22(2): 226-248. https://doi.org/10.2514/1.12793

[6] Nikitopoulos, D.E., Eliades, V., Acharya, S. (2001). Heat transfer enhancements in rotating two-pass coolant channels with profiled ribs: Part 2 - detailed measurements. J. Turbomach., 123(1): 107-114. https://doi.org/10.1115/1.1331538

[7] Mhetras, S., Narzary, D., Gao, Z., Han, J.C. (2008). Effect of a cutback squealer and cavity depth on filmcooling effectiveness on a gas turbine blade tip. Journal of Turbomachinery, 130(2): 021002. https://doi.org/10.1115/1.2776949

[8] Han, J.C., Ekkad, S. (2001). Recent development in turbine blade film cooling. International Journal of Rotating $\quad$ Machinery, $7(1)$ : 21-40. https://doi.org/10.1155/S1023621X01000033

[9] Han, J.C., Dutta, S., Ekkad, S. (2012). Gas Turbine Heat Transfer and Cooling Technology. CRC Press.

[10] Yang, H., Chen, H.C., Han, J.C. (2006). Film-cooling prediction on turbine blade tip with various film hole configurations. Journal of Thermophysics and Heat Transfer, 20(3): 558-568. https://doi.org/10.2514/1.18422

[11] Christophel, J.R., Thole, K.A., Cunha, F.J. (2005). Cooling the tip of a turbine blade using pressure side holes - part I: Adiabatic effectiveness measurements. J. Turbomach.,

127(2):

270-277. 
https://doi.org/10.1115/1.1812320

[12] Christophel, J.R., Thole, K.A., Cunha, F.J. (2005). Cooling the tip of a turbine blade using pressure side holes-part II: heat transfer measurements. J. Turbomach., $127(2)$ : https://doi.org/10.1115/1.1811096

[13] Kwak, J.S., Han, J.C. (2003). Heat transfer coefficients and film-cooling effectiveness on a gas turbine blade tip. J. Heat Transfer, 125(3): 494-502. https://doi.org/10.1115/1.1565096

[14] Chanteloup, D., Juaneda, Y., Bo“lcs, A. (2002). Combined 3-D flow and heat transfer measurements in a 2-pass internal coolant passage of gas turbine airfoils. J. Turbomach., $\quad$ 124(4): $\quad 710-718$ https://doi.org/10.1115/1.15061764

[15] Chanteloup, D., Bo"lcs, A. (2002). Flow characteristics in two-leg internal coolant passages of gas turbine airfoils with film-cooling hole ejection. J. Turbomach., 124(3): 499-507. https://doi.org/10.1115/1.1480412
[16] Acharya, S., Eliades, V., Nikitopoulos, D.E. (2001). Heat transfer enhancements in rotating two-pass coolant channels with profiled ribs: Part 1 - Average Results. J. Turbomach., 123(1): https://doi.org/10.1115/1.1331539

[17] Zhou, F., Lagrone, J., Acharya, S. (2004). Internal cooling in 4: 1 AR passages at high rotation numbers. Turbo Expo: Power for Land, Sea, and Air, 41685: 451460. https://doi.org/10.1115/GT2004-53501

\section{NOMENCLATURE}

$\begin{array}{ll}\mathrm{Nu} & \text { Nusselt number, no units } \\ \mathrm{Z} & \text { blade length, } \mathrm{m} \\ \mathrm{X} & \text { chord length, } \mathrm{m} \\ \mathrm{h} & \text { average heat transfer coefficient, } \mathrm{W} / \mathrm{m}^{2} \mathrm{~K} \\ \mathrm{D} & \text { diameter of the coolant passage, } \mathrm{m} \\ \mathrm{k} & \text { thermal conductivity of the coolant fluid, W/m K}\end{array}$

